Tropical Journal of Pharmaceutical Research, October 2009; 8 (5): 399-408

(C) Pharmacotherapy Group,

Faculty of Pharmacy, University of Benin

Benin City, 300001 Nigeria.

All rights reserved.

Research Article

Available online at http://www.tjpr.org

\title{
Cyperus scariosus Chloroform Fraction Inhibits T cell Responses in Balb/C Mice
}

\section{Deepak Bhagwat ${ }^{*}$, MD Kharya ${ }^{2}$, Sarang Bani ${ }^{3}$, Anjali Pandey ${ }^{3}$, Prashant Singh Chauhan ${ }^{3}$, Kiranjeet Kour ${ }^{3}$, KA Suri ${ }^{4}$, NK Satti and Prabhu Dutt ${ }^{4}$}

\begin{abstract}
${ }^{1}$ Pharmacology Research Laboratory, ASBASJSM College of Pharmacy, Bela (Ropar), 140111, PB, ${ }^{2}$ Department of Pharmaceutical Sciences, Dr. Hari Singh Gour University, Sagar, 470 003, M.P., ${ }^{3}$ Cell Biology Laboratory, Department of Pharmacology, Indian Institute of Integrative Medicine, Jammu Tawi, $180001 . \mathrm{J} \& \mathrm{~K}$, India, ${ }^{4}$ Natural Products Chemistry Division, Indian Institute of Integrative Medicine, Jammu Tawi, 180 001. J \& K, India.
\end{abstract}

\begin{abstract}
Purpose: To investigate the T cell inhibition potential of $50 \%$ ethanol extract of Cyperus scariosus (CS) and its bioactive chloroform fraction (CSC).

Methods: The preliminary screening of the extract was carried out by humoral antibody response and delayed-type hypersensitivity models employing sheep red blood cells (SRBC) as the antigen. Further, the extract was studied by skin allograft rejection test, and phagocytosis - in vitro and ex vivo - by $C$. albicans method and carbon clearance test, respectively. The extract was fractionated with chloroform, $n$-butanol and water, and then used to investigate the T-cell specific immunosuppressive potential of these fractions by flow cytometry.

Results: On p.o. administration, CS inhibited both humoral and cell-mediated immune responses significantly $(p<0.01)$ by suppressing primary $(26.8 \%)$ and secondary $(29.7 \%)$ antibody titres, and also inhibited cell-mediated delayed type hypersensitivity (DTH) immune response (45.9\%) at 600 $\mathrm{mg} / \mathrm{kg}$ dose, phagocytosis - both in vitro (37.4\%) and ex vivo (37.8 \%) - and delayed the graft rejection time (45.8\%), thus confirming marked immunosuppression. Out of the three isolated fractions, only the chloroform fraction significantly $(p<0.01)$ suppressed $C D 8+/ C D 4+T$ cell surface markers $(14.0 / 25.3$ $\%)$ and intra-cellular Th1 cytokines, viz, IL-2 (34.4\%), and IFN-Y (34.7\%), compared to cyclosporine-A (5), a standard T cell inhibitor (53.6 \%) which was given to Balb/C mice at $200 \mathrm{mg} / \mathrm{kg}$ dose. CSC did not significantly $(p<0.01)$ suppress Th2 (IL-4) system.

Conclusion: The findings from this investigation reveal that $C$. scariosus causes immunosuppression by inhibiting Th1 cytokines.
\end{abstract}

Keywords: Cyperus scariosus; Immunosuppression; Humoral antibody titre; Cell-mediated immune response; $C D 4+T$ - helper cells; $C D 8+T$ - cytotoxic cells 


\section{INTRODUCTION}

Cyperus sacriosus R. Br. (Family Cyperaceae), is an important medicinal plant in Indian Systems of Medicine and is indicated for inflammatory conditions of joints [1]. The present study was carried to investigate the immunomodulation potential of Cyperus scariosus (commonly known as Nagar motha in Hindi and Nagar musta in Sanskrit, Lawala in Marathi and Koraikkilangu in Tamil), which has been used in Indian Systems of Medicine (ISM) and by Ayurvedic practitioners for the treatment of inflammation, arthritis and stomach disorders [2]. The genus Cyperus is widely distributed throughout the world and consists of about 700 species of which around 60 species occur in India. Some of them are used as fodder; a few, yielding culms and leaves, are used for matting, and yet others yielding tuberous rhizomes are used for edible, medicinal and perfumery purposes [3]. The plant has yielded many biogenetically important phyto-constituents.

The chief chemical constituent of Cyperus scariosus is the essential oil, which is a mixture of at least 21 compounds, most of which are sesquiterpenes, such as cyperene, rotundene, rotundenol, isopatchoula-3,5diene, isopatchoul-3-ene, $\quad \beta$-selinene, isopatchoulenol and scariodione. Ketones, hydrocarbons and a saponin have also been reported [4]. The essential oil of this plant has been found to be effective in treating exudative and proliferative phase of inflammation and also suppressed adjuvant induced arthritis [5]. This substantiates the folkloric usefulness of this plant in the Indian system of medicine. In an in vitro study, it suppressed the spontaneous contractions of guinea pig paired atria, rat uterus and rabbit jejunum in a concentration-dependent manner, and also inhibited histamine and acetylcholine-induced contractions of guinea pig ileum, indicating non-specific spasmolytic action [6].

Inspired by the therapeutic virtues of the plant and taking lead from its conventional uses, we have investigated the immunomodulation potential of Cyperus scariosus extract (CS) and its corresponding chloroform fraction (CSC) as well as its putative role in alleviating inflammatory conditions of the body.

\section{EXPERIMENTAL}

\section{Plant material}

C. scariosus roots were collected from the local market of Sagar, Madhya Pradesh, India and authenticated by routine pharmacognostic procedures by $\mathrm{Dr} \mathrm{BK}$ Kapahi, Senior Botanist, Indian Institute of Integrative Medicine (IIIM), Jammu, India. A voucher specimen was retained and deposited at the crude drug repository of the herbarium of IIIM, vide CDR accession no. 3234. The test material was prepared as fresh suspensions using $1 \%$ sterile gum acacia in sterilized distilled water.

\section{Preparation of extract and fractions}

Cyperus scariosus roots $(2 \mathrm{~kg})$ were macerated with ethanol : water (1:1) with constant stirring at $1200 \mathrm{rpm}$ at room temperature for $3 \mathrm{~h}$. The extract was filtered and the marc was drained. The marc was subjected to the same extraction procedure thrice to complete extraction. The combined extract was reduced to $1 / 8^{\text {th }}$ of its original volume with a rotary evaporator (Heidolph Laborota 4000 ) at $50^{\circ} \mathrm{C}$ and lyophilized (Telstar Lyobeta 35), giving a yield of $186 \mathrm{~g}$. The lyophilized extract was macerated with chloroform, and the chloroform-soluble portion was separated and evaporated on a rotavapor to obtain the chloroform fraction which weighed $8.26 \mathrm{~g}$. The chloroform insoluble portion was partitioned between nbutanol and water to obtain n-butanol (53.42 g) and water (124.32 g) fractions.

\section{Animals}

Male Balb/C mice (Mus musculus) 8-10 weeks old and weighing 18-22 g, in groups of six, were used for the study. The protocol for acute toxicity and ex vivo studies on immunomodulatory activity was approved by 
Institutional Animal Ethics Committee (IAEC) of Dr. HS Gour University, Sagar, M.P. (CPCSEA registration No. 379/01/ab/ CPCSEA; vide approval no. Animal Eths.Comm./DB/98). The animals were housed under standard laboratory conditions - $23 \pm 1{ }^{\circ} \mathrm{C}, 55 \pm 10 \%$ relative humidity, $12 / 12$ $\mathrm{h}$ light/dark cycles, fed with standard pellet diet (Lipton India Ltd) and received water $a d$ libitum. None of the animals was sacrificed throughout the study; however, as per the institute's norms, the animals, after experimentation, were subjected to euthanasia by a high inhalational dose of diethyl ether and disposed off by incineration.

\section{Drugs}

i) Drugs for oral administration were freshly prepared as a homogenized suspension of $C$. scariosus extract (CS) in doses of 50,100, 200, 400, 600 and $800 \mathrm{mg} / \mathrm{kg}$ and $C$. scariosus chloroform fraction (CSC) in doses of $25,50,100$, and $200 \mathrm{mg} / \mathrm{kg}$ in $1 \% \mathrm{w} / \mathrm{v}$ acacia gum and administered orally to Balb/C mice once daily for the duration of the experiment.

ii) Cyclophosphamide and cyclosporine-A were used as standard immunosuppressive agents at doses of 250 and $5 \mathrm{mg} / \mathrm{kg} \mathrm{p.o.} \mathrm{for} \mathrm{B}$ cell and $\mathrm{T}$ cell suppression, respectively .

\section{Chemicals}

Fluoroisothiocyanate (FITC)-labeled CD4 anti-mouse monoclonal antibody, phycoerytherin (PE)-labeled CD8 anti-rat monoclonal antibody, FACS lysing solution, FACS permeabilising solution, Golgi plug, IL2 monoclonal antibody anti-mouse (PE), IFN$\gamma$ - monoclonal antibody anti-mouse (FITC), TNF- $\alpha-$ monoclonal antibody anti-rat (BD Biosciences); phosphate buffer saline, ethylene diamine tetraacetic acid (EDTA) (Sigma Aldrich), and heparin (Sigma Aldrich) were used. All other reagents used were of analytical grade.

\section{Antigenic stimulus}

Fresh sheep red blood cells (SRBC) collected aseptically from the jugular vein of sheep stored in cold sterile Alsever's solution, were washed three times with pyrogen-free sterile normal saline $(0.9 \% \mathrm{NaCl})$. Cell count was adjusted to $5 \times 10^{9}$ cells $/ \mathrm{mL}$ for immunisation and challenged at the required times.

\section{Blood collection}

On specified days, as per the protocol, blood was drawn from retro-orbital plexus of the animals into a sterile tube with EDTA as an anti-coagulant.

\section{General behavior and acute toxicity test}

Acute oral toxicity studies were carried out following OECD guidelines no. 423 [7] after approval from the Institutional Animal Ethics Committee (IAEC). Three female Balb/C mice, fasted $3-4 \mathrm{~h}$ prior to the test, were used for each step and observed individually after dosing at least once during the first 30 min, and periodically during the first $24 \mathrm{~h}$, with special attention given during the first 4 $h$, and daily thereafter, for a total of 14 days. Simultaneously, general behavior and any toxic symptoms produced by the test material were observed for 14 days for routine pharmacological parameters such as cyanosis, tremors, convulsions, ataxia, body tone, muscle tone, piloerection, salivation, tail flick, drowsiness, alertness, spontaneity, diarrheoa, pupil size, ptosis, breathing rate, urination etc.

\section{Selection of doses}

No toxic symptoms were observed in mice up to $2000 \mathrm{mg} / \mathrm{kg}$ p.o. dose $\left(L_{0}\right)$. Evaluation of the test material was initiated by giving to the mice $1 / 10^{\text {th }}$ of this dose $(200 \mathrm{mg} / \mathrm{kg})$ as well as lower $(100 \mathrm{mg} / \mathrm{kg})$ and higher $(400 \mathrm{mg} / \mathrm{kg})$ doses. It was observed that the effect increased significantly $(p<0.01)$ at $400 \mathrm{mg} / \mathrm{kg}$ dose and, therefore, higher doses (600 and $800 \mathrm{mg} / \mathrm{kg}$ ) were also explored. 


\section{Humoral antibody response}

Mice $(\mathrm{n}=6)$ were immunised by injecting 200 $\mu \mathrm{L}$ of $5 \times 10^{9} \mathrm{SRBC} / \mathrm{mL}$ intraperitoneally (i.p) on day 0 . C. scariosus extract $(C S)$ was administered to the mice in graded doses $(50,100,200,400,600$ and $800 \mathrm{mg} / \mathrm{kg}$ body wt) for seven days. The blood samples were collected on day +7 (before challenge) for $1^{\circ}$ Antibody titre and on day +14 ( 7 days after challenge) for $2^{\circ}$ Antibody titre. Hemagglutination Antibody titres were determined following the micro-titration technique [8]. BSA-saline served as control.

\section{Delayed-type hypersensitivity (DTH) response}

$C S$ at doses of 50,100,200,400, 600 and $800 \mathrm{mg} / \mathrm{kg}$ p.o. was administered after SRBC sensitization to mice and once daily on consecutive days. Six days later, the thickness of the left hind foot was measured with a spheromicrometer (pitch, $0.01 \mathrm{~mm}$ ) and was considered as a control. The mice were then challenged by injecting the same amount of SRBC intra-dermally into the right hind footpad. The foot thickness was measured again after $24 \mathrm{~h}$ [9].

\section{Skin allograft rejection}

The $50 \%$ ethanol (EtOH) extract of $C$. scariosus (CS) was administered to mice at doses of $50-800 \mathrm{mg} / \mathrm{kg}$ for 7 days and graft rejection time (GRT) was recorded by daily observations of epithelial skin layer survival. Control group was given only vehicle and another group received cyclosporine-A as standard at $5 \mathrm{mg} / \mathrm{kg}$ daily for 7 days [10].

\section{In vitro phagocytic response}

The phagocytic function of peritoneal macrophages were assessed by harvesting murine peritoneal macrophages by flushing the peritoneal cavity with $5 \mathrm{ml}$ of sterile ice cold $0.15 \mathrm{mM}$ phosphate buffer saline (PBS) containing 2 units $/ \mathrm{ml}$ of preservative free heparin. The number of viable nucleated cells was determined by trypan blue dye exclusion test in a hemocytometer. The cells from the suspension were allowed to adhere to glass cover slips for $2 \mathrm{~h}$ at $37{ }^{\circ} \mathrm{C}$ in $5 \% \quad \mathrm{CO}_{2}$ incubator with $50-800 \mu \mathrm{g} / \mathrm{ml}$ concentrations of PL (Group III-VIII), $10 \mu \mathrm{g} / \mathrm{ml}$ concentration of cyclosporine-A. Group I served as control.

The non adherent cells were washed with PBS and heat-killed Candida albicans cells opsonized with $20 \%$ mouse serum for 90 min. An aliquot $(100 \mu l)$ of these $C$. albicans cells was incubated with macrophages and incubated for $15 \mathrm{~min}$ at $37^{\circ} \mathrm{C}$ in $5 \% \mathrm{CO}_{2}$ and $95 \% \mathrm{RH}$. The cover slips were washed thoroughly with PBS and stained with trypan eosin. The percentage and average number of Candida albicans cells (heat-killed) ingested by peritoneal murine macrophages were calculated [11].

\section{Ex vivo phagocytic response}

The phagocytic function of the reticuloendothelial system was assayed in groups of six mice each by injecting i.v. 160 $\mathrm{mg} / \mathrm{kg}$ of $1.6 \%$ suspension of gelatin stabilized carbon particles of $20-25 \mu \mathrm{m}$ size [12]. Blood samples were collected before carbon injection and at intervals varying between 2 and 90 min thereafter. An aliquot $(10 \mu \mathrm{L})$ of the blood samples was lysed with $2 \mathrm{~mL}$ of $0.1 \%$ acetic acid and its transparency determined spectrophotometrically at $675 \mathrm{~nm}$ (Uvikon 810, spectrophotometer, Kontron Ltd, Switzerland). CS was administered orally for 7 days and 30 min prior to the carbon injection in a dose range of $50-800 \mathrm{mg} / \mathrm{kg}$ [13].

\section{Evaluation of $\mathrm{T}$ cell surface markers by flow cytometry}

For T cell surface markers estimation, mice in groups (I to VII) were immunised on day 0 by injecting $200 \mu \mathrm{L}$ of $5 \times 10^{9} \mathrm{SRBC} / \mathrm{mL}$ intraperitoneally (i.p). C. scariosus chloroform fraction (CSC) at doses of 25, 50, 100 and 
$200 \mathrm{mg} / \mathrm{kg}$, respectively (Groups IV - VII) and cyclosporine-A (Group III) at a dose of 5 $\mathrm{mg} / \mathrm{kg}$, were administered for +7 days including the day of immunisation. On +8 day, the animals from groups II - VII were challenged with sheep RBCs (SRBC). On +10 day, the animals were bled retro-orbitally and blood was collected in EDTA-coated tubes for CD4+/CD8+ $T$ cell surface markers estimations. Group I served as normal control (NC) and Group II as sensitized control (SC).

Lymphocyte subsets were measured by immunofluorescent antibody staining of whole blood and subsequently analysed using twocolour flow cytometry (Becton \& Dickinson, UK). Murine monoclonal antibodies conjugated to a fluorochrome and directed against receptors CD4 and CD8 were used for the study. The fluorochrome-labeled monoclonal antibodies were added directly to $100 \mu \mathrm{L}$ of whole blood, which was then lysed using whole blood lysing reagent (BD Biosciences). Following final centrifugation, samples were re-suspended in phosphatebuffered saline ( $\mathrm{pH} 7.4)$ and analyzed directly on the flow cytometer (LSR, BD Biosciences) using Cell Quest Pro Software (BD Biosciences). A fluorescence trigger was set on the FITC (FL1) parameter to analyze CD4+ and PE (FL2) parameter to collect CD8+ events [14].

\section{Estimation of intracellular cytokines by flow cytometry}

Mice in groups (I to VII) were immunised on day 0 by injecting $200 \mu \mathrm{L}$ of $5 \times 10^{9} \mathrm{SRBC} / \mathrm{mL}$ intraperitoneally (i.p.). CSC at doses of 25, 50, 100 and $200 \mathrm{mg} / \mathrm{kg}$ (Groups IV - VII) and cyclosporine-A at a dose of $5 \mathrm{mg} / \mathrm{kg}$ (Group III) were administered for +7 days including the day of immunization. On +8 day, the animals from groups II - VII were challenged with sheep RBCs (SRBC). On +10 day, the animals were bled retro-orbitally and blood was collected in EDTA-coated tubes for the estimation of Th1 cytokines, such as IL-2 and IFN- $y$, and Th2 cytokine, IL-4 [15]. Group I served as normal control and Group II as sensitised control. Analysis was done on a flow cytometer (BD Biosciences, USA).

\section{Statistical analysis}

Data were expressed as the mean \pm standard error of the means (S.E.) for six mice per group, and statistical analysis was carried out using Dunnett test with the aid of Instat 3 software.

\section{RESULTS}

Prior to the animal experiments, toxicity studies were carried out for dose standardisation, in which it was observed that $\mathrm{LD}_{0}$ of $C S$ was $2000 \mathrm{mg} / \mathrm{kg}$ dose and none of the animals showed toxic signs and symptoms.

\section{Humoral antibody response}

CS, on oral administration at doses ranging from 50 - $800 \mathrm{mg} / \mathrm{kg}$, produced a doserelated decrease in primary antibody formation. However, maximum effect was observed at $600 \mathrm{mg} / \mathrm{kg}$ (26.8\% decrease) after which the suppressive effect waned to $22 \%$ at $800 \mathrm{mg} / \mathrm{kg}$ oral dose. Cyclophosphamide (as standard) showed $31.8 \%$ decrease in the antibody formation at a dose of $250 \mathrm{mg} / \mathrm{kg}$ (Table 1). CS more effectively decreased secondary antibody production, in which the maximum suppression (29.7\%) was noticed at 600 $\mathrm{mg} / \mathrm{kg}$ dose. Cyclophosphamide decreased antibody formation by $36.4 \%$ in terms of secondary antibody titres (Table 1).

\section{Delayed-type hypersensitivity response}

(DTH)

CS (50 - $800 \mathrm{mg} / \mathrm{kg}$ p.o.) showed a decrease of $11.5-45.9 \%$ in DTH response in mice. The most pronounced effect was observed at the dose of $600 \mathrm{mg} / \mathrm{kg}(\mathrm{p}<0.01)$. The effect of $C S$ at $800 \mathrm{mg} / \mathrm{kg}$ was reduced to $44.3 \%$. Cyclosporine A $(5 \mathrm{mg} / \mathrm{kg}$ ) produced a $57.4 \%$ decrease (Table 1 ). 
Table 1: Effect of Cyperus scariosus (CS) on SRBC induced primary (Habt) and secondary (Sabt) humoral immune response and delayed-type hypersensitivity (DTH) or CMI response in mice.

\begin{tabular}{|c|c|c|c|c|c|c|}
\hline \multirow{3}{*}{$\begin{array}{l}\text { Treatment dose } \\
(\mathrm{mg} / \mathrm{kg}, \text { p.o.) }\end{array}$} & \multicolumn{3}{|c|}{ Humoral Immune Response } & \multirow{2}{*}{\multicolumn{3}{|c|}{$\begin{array}{l}\text { Cell Mediated Immune response } \\
\text { Paw swelling }(\mathrm{mm}) \text { in mice day } 7\end{array}$}} \\
\hline & \multicolumn{2}{|c|}{ Habt $\left[\log _{2}\right] 7^{\text {th }}$ Day } & \multirow{2}{*}{$\begin{array}{c}\begin{array}{c}\text { Sabt }\left[\log _{2}\right] \\
14^{\text {th }} \text { Day }\end{array} \\
\text { (Mean } \pm \text { S.E.) }\end{array}$} & & & \\
\hline & (Mean \pm S.E.) & $\%$ Change & & $\%$ Change & (Mean \pm S.E.) & $\%$ Change \\
\hline Control SRBC & $6.83 \pm 0.16$ & - & $7.33 \pm 0.21$ & - & $0.61 \pm 0.01$ & - \\
\hline $\begin{array}{l}\text { Cyclophosphamide } \\
\text { (250) }\end{array}$ & $4.66 \pm 0.21^{* *}$ & $31.77 \downarrow$ & $4.66 \pm 0.33^{\star *}$ & $36.42 \downarrow$ & - & - \\
\hline Cyclosporine A (5) & - & - & - & - & $0.26 \pm 0.02^{* *}$ & $57.37 \downarrow$ \\
\hline $\operatorname{CS}(50)$ & $6.66 \pm 0.21$ & $2.48 \downarrow$ & $7.00 \pm 0.25$ & $4.52 \downarrow$ & $0.54 \pm 0.02^{*}$ & $11.47 \downarrow$ \\
\hline $\begin{array}{l}C S(100) \\
C S(200) \\
C S(400) \\
C S(600) \\
C S(800)\end{array}$ & $\begin{array}{l}6.33 \pm 0.21 \\
6.00 \pm 0.25 \\
5.66 \pm 0.21^{\star *} \\
5.00 \pm 0.25^{\star *} \\
5.33 \pm 0.21^{* *}\end{array}$ & $\begin{array}{l}7.32 \downarrow \\
12.15 \downarrow \\
17.13 \downarrow \\
26.79 \downarrow \\
21.96 \downarrow\end{array}$ & $\begin{array}{l}6.50 \pm 0.22^{*} \\
6.16 \pm 0.16^{\star *} \\
5.85 \pm 0.16^{\star \star} \\
5.16 \pm 0.16^{\star \star} \\
5.50 \pm 0.22^{* \star}\end{array}$ & $\begin{array}{l}11.32 \downarrow \\
15.96 \downarrow \\
20.46 \downarrow \\
29.72 \downarrow \\
24.96 \downarrow\end{array}$ & $\begin{array}{l}0.50 \pm 0.02^{* *} \\
0.41 \pm 0.01^{* *} \\
0.37 \pm 0.02^{* *} \\
0.33 \pm 0.01^{* *} \\
0.34 \pm 0.02^{* *}\end{array}$ & $\begin{array}{l}18.03 \downarrow \\
32.78 \downarrow \\
39.34 \downarrow \\
45.90 \downarrow \\
44.26 \downarrow\end{array}$ \\
\hline
\end{tabular}

${ }^{*} p<0.05 ;{ }^{* *} p<0.01$ (Dunnett test); Habt, humoral antibody titre (primary); Sabt, secondary antibody titre;

$(\downarrow)$ reduction in activity; number of animals per group $=6$; $C M I=$ cell mediated immunity.

Table 2: Effect of Cyperus scariosus (CS) on homologous graft rejection in mice

\begin{tabular}{llll}
\hline Group & Treatment $(\mathrm{mg} / \mathrm{kg})$ & $\begin{array}{l}\text { Rejection Time } \\
\text { (Mean } \pm \text { S.E.) }\end{array}$ & \% Activity \\
\hline I & Naive Control (NC) & $12.00 \pm 0.25$ & - \\
II & Cyclosporine-A (5) & $19.00 \pm 0.25^{\star *}$ & $58.33 \uparrow$ \\
III & CS $(50)$ & $13.00 \pm 0.25$ & $8.33 \uparrow$ \\
IV & CS $(100)$ & $13.33 \pm 0.21^{\star *}$ & $11.08 \uparrow$ \\
V & CS $(200)$ & $14.33 \pm 0.21^{\star *}$ & $19.41 \uparrow$ \\
VI & $C S(400)$ & $15.50 \pm 0.34^{* *}$ & $29.16 \uparrow$ \\
VII & $C S(600)$ & $17.00 \pm 0.25^{\star *}$ & $41.66 \uparrow$ \\
VIII & $C S(800)$ & $17.50 \pm 0.34^{* *}$ & $45.83 \uparrow$ \\
\hline
\end{tabular}

\section{Skin allograft rejection}

CS at $50-800 \mathrm{mg} / \mathrm{kg}$ delayed skin allograft rejection time in mice. The maximum delay in graft rejection was $45.8 \%$ at $800 \mathrm{mg} / \mathrm{kg}(\mathrm{p}<$ $0.01)$. However, $C S$ at p.o. doses ranging from 50 - $600 \mathrm{mg} / \mathrm{kg}$ delayed the graft rejection time in a dose-dependent manner by between 8.3 and $41.7 \%$ as indicated in Table 2.

\section{In vitro phagocytic response}

CS was administered to mice at the doses of $50,100,200,400,600$ and $800 \mu \mathrm{g} / \mathrm{mL}$. The results are shown in Table 3 . Significant decreases in phagocytosis of heat killed Candida albicans by murine macrophages were observed at doses of 400,600 , and 800 $\mu \mathrm{g} / \mathrm{mL}$, the effect being 27.0, 37.4 and 36.6 $\%$, respectively $(p<0.01)$. This compares with cyclosporine $A(10 \mu \mathrm{g} / \mathrm{mL})$ which showed $47.1 \%$ decrease $(p<0.01)$.

\section{Ex vivo phagocytic response}

Administration of $C S$ to mice over a period of 7 days decreased the rate of clearance of carbon particles from circulation (Table 3). The decrease in phagocytic index was 4.7 - 
Bhagwat et al

Table 3: Effect of Cyperus scariosus (CS) on phagocytic function of murine macrophages

\begin{tabular}{|c|c|c|c|}
\hline $\begin{array}{l}\text { Treatment } \\
\text { dose }(\mu \mathrm{g} / \mathrm{mL})\end{array}$ & $\begin{array}{l}\text { Phagocytosis } \\
\text { (in vitro) } \\
\text { Mean } \pm \text { S.E.(\%) }\end{array}$ & $\begin{array}{l}\text { Treatment } \\
\text { (dose } \mathrm{mg} / \mathrm{kg} \text { ) }\end{array}$ & $\begin{array}{l}\text { Phagocytic Index (ex } \\
\text { vivo) } \\
\text { Mean } \pm \text { S.E.(\%) }\end{array}$ \\
\hline Naïve Control & $26.44 \pm 1.09$ & Naïve Control & $1.27 \pm 0.11$ \\
\hline Cyclosporine-A (10) & $13.98 \pm 0.46^{\star *} \quad(47.12) \downarrow$ & Cyclosporine-A (5) & $0.70 \pm 0.15^{\star *}(44.88) \downarrow$ \\
\hline $\operatorname{CS}(50)$ & $25.70 \pm 0.33 \quad(2.79) \downarrow$ & $\operatorname{CS}(50)$ & $1.21 \pm 0.10(4.72) \downarrow$ \\
\hline$C S(100)$ & $24.18 \pm 0.29 \quad(8.54) \downarrow$ & CS (100) & $1.18 \pm 0.28 \quad(7.08) \downarrow$ \\
\hline CS (200) & $21.89 \pm 0.71^{* \star} \quad(17.20) \downarrow$ & CS (200) & $1.09 \pm 0.12 \quad(14.17) \downarrow$ \\
\hline CS (400) & $19.31 \pm 0.31^{\star *} \quad(26.96) \downarrow$ & $\operatorname{CS}(400)$ & $0.92 \pm 0.21^{\star *}(27.55) \downarrow$ \\
\hline CS (600) & $16.54 \pm 1.24^{* *} \quad(37.44) \downarrow$ & $C S(600)$ & $0.80 \pm 0.10^{* \star}(37.00) \downarrow$ \\
\hline $\operatorname{CS}(800)$ & $16.77 \pm 0.55^{\star *} \quad(36.57) \downarrow$ & $\operatorname{CS}(800)$ & $0.79 \pm 0.21^{\star *}(37.79) \downarrow$ \\
\hline
\end{tabular}

" $p<0.01$ (Dunnett test); Figures in parentheses represent \% change in activity; number of animals per group $=6$.

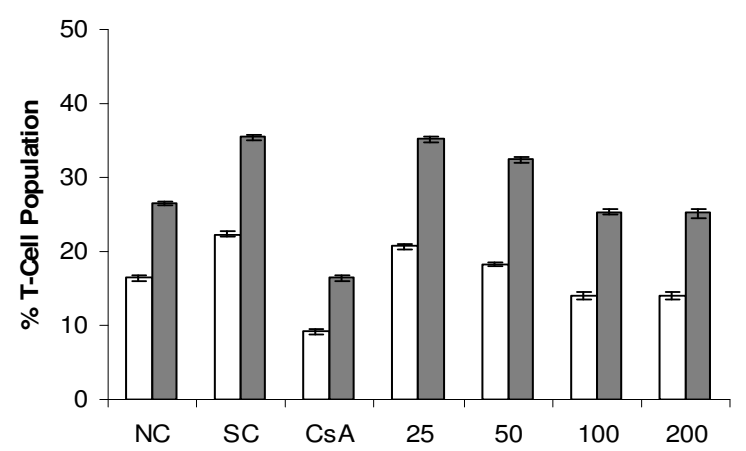

Fig 1: Effect of chloroform fraction of Cyperus scariosus (CSC) on CD8+ / $\square$ CD4+ T cell surface marker population. $\left({ }^{* *} \mathrm{p}<0.01 ; \mathrm{NC}=\right.$ normal control; $\mathrm{SC}=$ sensitized control; CsA = cyclosporine A $(5 \mathrm{mg} / \mathrm{kg})$; CSC = Cyperus scariosus chloroform fraction

$37.8 \%$ in the dose range of $50-800 \mathrm{mg} / \mathrm{kg}$ compared with cyclosporine A $(5 \mathrm{mg} / \mathrm{kg})$ which produced $44.9 \%$ decrease $(p<0.01)$ in phagocytosis. The effect was statistically highly significant at higher doses $(p<0.01)$.

\section{Lymphocyte immunophenotyping}

CSC showed maximum effect at $100 \mathrm{mg} / \mathrm{kg}$ dose which accounted for $14.0 \pm 0.4 \%$ of CD8+ and $25.3 \pm 0.4 \%$ of CD4+ T cells $(p<$ 0.01 ). The control values were $22.3 \pm 0.3 \%$ of CD8+ and $38.6 \pm 0.4 \%$ of CD4+ T cells. This shows a significant suppression of CD8+ and CD4+ T cell population $(p<0.01)$. On the other hand, cyclosporine $A(5 \mathrm{mg} / \mathrm{kg})$, a standard $T$ cell inhibitor, significantly $(p<$ 0.01) inhibited both CD8+ and CD4+ T cells by $9.2 \pm 0.4$ and $16.5 \pm 0.4$, respectively, as shown in Fig 1.

\section{Intracellular cytokine estimation}

The results of the effect of the test material on cytokines IL-2 and IFN- $\gamma$ are displayed in Fig 2. Both IL-2 and IFN- $\gamma$ counts were downregulated. The reduction in IL-2 by CSC was observed at all dose levels with a maximum expression of $23.2 \pm 0.3 \%$ in CD4+ + T cells $(p<0.01)$ at a dose of $200 \mathrm{mg} / \mathrm{kg}$. IL-2 in the sensitized control group was $35.3 \pm 0.5 \%$ while IFN- $\gamma$ decreased from $17.4 \pm 0.5$ (sensitized control) to $11.4 \pm 0.6 \%$ in CSCtreated group at a dose of $100 \mathrm{mg} / \mathrm{kg}$ ( $\mathrm{p}<$ 0.01). However, cyclosporine A (as standard) significantly $(p<0.01)$ decreased IL-2 and 


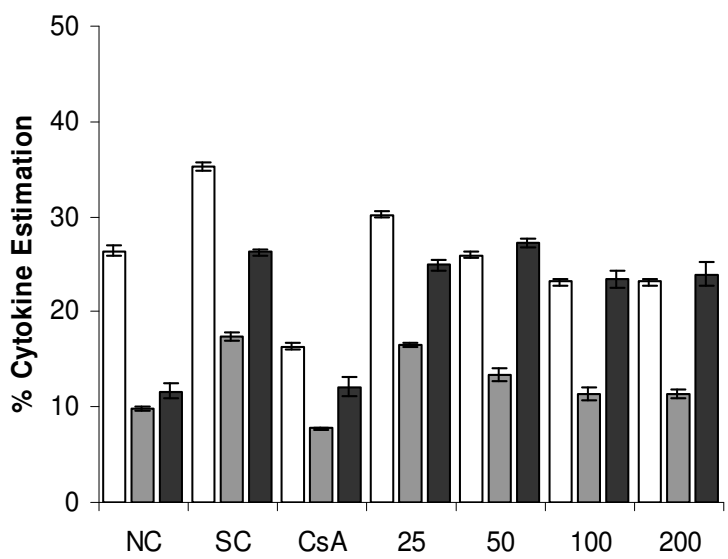

Fig 2: Effect of chloroform fraction of Cyperus scariosus (CSC) on IL-2 (口), IFN- $\gamma(\square)$ and IL-4 ( $\square$ ) populations. $\left({ }^{*} \mathrm{p}<0.01 ; \mathrm{NC}=\right.$ normal control; $\mathrm{SC}=$ sensitized control; CsA = cyclosporine A $(5 \mathrm{mg} / \mathrm{kg}) ; \mathrm{CSC}=$ Cyperus scariosus chloroform fraction

IFN- $\gamma$ by $16.4 \pm 0.3$ and $7.7 \pm 0.2 \%$, respectively (see Fig. 2).

IL-4 in the normal sensitized group was 26.2 $\pm 0.4 \%$. The maximum inhibition of IL-4 in CD $4+\mathrm{T}$ cells was $23.4 \pm 1.0 \%$ at $100 \mathrm{mg} / \mathrm{kg}$ dose p.o.; this inhibition was not significant ( $p$ $<0.01$ ) On the other hand, cyclosporine Atreated group showed a significant decrease $(p<0.01)$ in IL-4 of $11.48 \pm 0.67$ at a dose of $5 \mathrm{mg} / \mathrm{kg}$ p.o. dose.

\section{DISCUSSION}

The present study was aimed to investigate the immunosuppressive property of Cyperus scariosus and its therapeutic potential as an anti-inflammatory agent. The experimental design was in two phases. In the first phase, $50 \% \mathrm{EtOH}$ extract of C. scariosus (CS) was explored for its immunosuppressive properties, and this was indicated by the significant decrease in humoral and cell mediated responses. The results of macrophage phagocytic response confirmed the immunosuppressive properties of CS. These results prompted us to embark on the second phase which was to extend the studies to the bioactive fractions. Out of the three fractions obtained from $C S$ extract (chloroform, n-butanol and water fractions) the chloroform fraction (CSC) showed marked immunosuppressive and antiinflammatory activities, as evidenced from the results of lymphocyte immunophenotyping of T cell surface markers (CD8+/CD4+), which were down-regulated by CSC (see Fig 1), and the expression of intracellular Th1 (IL-2 and IFN-y) and Th2 (IL-4) cytokines (as shown in Fig 2). T cells expressing CD4 are increased when the physiological systems of the body are stimulated due to the activation of the non-specific immune status, and inhibition of this phenomenon indicates immunosuppression. When the body's defense mechanism is threatened by microorganisms or any other foreign invaders, macrophages are activated at the site of invasion to combat infections. CD 4+ T cell inhibition by $C$. scariosus may be one of the factors responsible for the decrease in the functioning of the macrophages. The reduced responsiveness of the phagocytes is evident by the decrease in the clearance of carbon particles from the reticuloendothelial system and also in the reduction in the rate of in vitro phagocytosis by murine macrophages, thus suggesting a reduction in the functioning of macrophages (Table 2). CSC was demonstrated to inhibit IL-2 
production by CD4+ $\mathrm{T}$ cells in a dosedependent manner (Fig. 1). IL-2 is a growth factor for Th1 cytokines. Possibly, the inhibition of IL-2 is responsible for the reduced secretion of IFN- $\gamma$ by CD $8+T$ cells. Apart from its role in $T$ cell activation, IFN- $Y$ is known to be central to full blown activation of macrophages [16] and its inhibition by CSC may be one of the important factors causing reduction in macrophage function $[17,18]$. CSC did not show significant reduction in IL-4 expression, which suggests that $C$. scariosus has little effect on Th 2 system.

Th1/Th2 paradigm not only allows a better understanding of the main mechanisms involved in the protection and pathogenesis of several immunopathic disorders, but also provides the basis for cytokine-induced immune deviation. The findings outlined above have demonstrated that $C$. scariosus has a potent $T$ cell suppressive activity and this is suggestive of its possible therapeutic usefulness in the treatment of inflammatory states of the body and auto-immune disorders such as arthritis. However, its clinical margin of safety in long-term therapeutics has to be established along with its biopharmaceutical evaluation prior to further therapeutic consideration.

\section{CONCLUSION}

The findings from the present investigation reveal that $C$. scariosus causes immunosuppression by inhibiting Th1 cytokines. However, it has little or no effect on Th2 cytokines.

\section{AKNOWLEDGEMENT}

We thank Dr GN Qazi, Ex-Director, Indian Institute of Integrative Medicine, Jammu-Tawi for giving us the opportunity to carry out the present investigation and providing the required facilities.

\section{REFERENCES}

1. Vaidya LC. Athaamvatadhikaar. In: Sri Bhav Mishra Virachit Bhavprakash (3 ${ }^{\text {rd }}$ Edn) Motilal Banarasidas Publishers, Varanasi, 1970 ; pp 223-231.

2. Chopra RN, Nayar SL, Chopra IC. Glossary of Indian Medicinal Plants. Council of Scientific and Industrial Research, New Delhi, India, 1956; $p 214$.

3. The Wealth of India. Publications and Information Directorate, Council of Scientific and Industrial Research, New Delhi, 1950, vol. II, Reprint 1988, p 425.

4. Nerali SB, Chakravarti KK. Terpenoids CXVII Structures of cyperenol and patchoulenol. Two new sesquiterpene alcohols from the oil of Cyperus scariosus. Tetrahedron Lett, 1967; 26: 2447-2449.

5. Gupta SK, Sharma RC, Aggarwal OP, Arora RB. Anti-inflammatory activity of the oil isolated from Cyperus scariosus (R. Br.). Indian J Exp Biol, 1972; 10: 41- 42.

6. Gilani $A H$, Janbaz $K H$, Jaman $N$, Lateef $A$, Tariq SR, Ahmad HR. Hypotensive and spasmolytic activities of crude extract of Cyperus scariosus. Arch Pharm Res, 1994; 17: 145149.

7. Organization for Economic Cooperation and Development. OECD guidelines for testing of chemicals. Guideline 423, Acute oral toxicity acute toxic class method, adopted March 22, 1996.

8. Nelson DS, Mildenhall P. Studies on cytophilic antibodies. The production by mice macrophage cytophilic antibodies to sheep erythrocytes: relationship to the production of other antibodies and development of delayedtype hypersensitivity. Aust J Exp Biol Med Sci, 1967; 45: 113-130.

9. Doherty, NS. Selective effect of immunosuppressive agents against the delayed hypersensitivity response and humoral response to sheep red blood cells in mice. Agents Actions, 1981; 11: 237-242.

10. Billingham RE, Medawar $P B$. The technique of free skin grafting in mammals. J Exp Biol, 1951; 28: 385-402.

11. Lehrer RI. Ingestion and destruction of Candida albicans. In: Methods for Studying MonoNuclear Phagocytes. Adams DO, Edelson PJ, Koren $H$ (eds). Academic Press, New York, 1981, pp 693-708.

12. Atal CK, Sharma ML, Kaul A, Khajuria $A$. Immunomodulating agents of plant origin. Part 1: preliminary screening. J Ethnopharmacol, 1986; 18: 133-141.

13. Hudson L, Hay, FC. Practical Immunology (2nd edn) Blackwell Publishers, London, 1980, pp 73-92.

14. Bani S, Kaul A, Khan B, Ahmad SF, Suri KA, Satti NK. Imunosuppressive properties of an ethyl 


\section{Bhagwat et al}

acetate fraction from Euphorbia royleana. $J$ Ethnopharmacol, 2005; 99: 185-92.

15. Bani S, Kaul A, Khan B, Sheikh FA, Suri KA, Gupta $B D$, Satti NK, Qazi G.N. Suppression of $T$ lymphocyte activity by lupeol isolated from Crataeva religiosa. Phytother Res, 2006; 20: 279-287.

16. Wang J, Wakeham J, Harkness $R$, Xing $Z$. Macrophages are a significant source of type 1 cytokines during mycobacterial infection. J Clin Invest, 1999; 103: 1023-1029.

17. Mosmann TR, Sad S. The expanding universe of Tcell subsets: Th1, Th2 and more. Immunol Today, 1996; 17: 138-146.

18. Xing Z, Jordana M, Gauldie J, Wang J. Cytokines and pulmonary inflammatory and immune diseases. Histol and Histopathol, 1999; 14: 185-201. 